\author{
Marcin Niemczyk \\ University of Rzeszów, Poland \\ ORCID: 0000-0001-8095-3239 \\ niemczykmarcin@wp.pl
}

\title{
Ancient Greek Rhetorical Speeches as a Source of Political Realism Idea
}

\author{
Starożytne greckie mowy retoryczne jako źródło idei \\ politycznego realizmu

\section{SUMMARY}

From the perspective of the history of political and legal doctrines, the dichotomous way of looking at actuality through the prism of the struggle between realism and idealism is one of the classical approaches to social sciences. The basic source of knowledge for the political realism idea is the achievements of politicians, historians and philosophers, who are often at the same time creators of political and legal thought. In the research on political realism, however, one should, based on subsidiarity, also use the message found in the rhetorical speeches, recorded and preserved until today. Taking these reservations into account, the subject of the article is to analyze - in a rhetorical perspective - the classical political realism, with the simultaneous narrowing of the research field to international relations. The subject of the analysis are selected ancient Greek rhetorical speeches by authors such as Cleon, Diodotus, Pericles, Demosthenes, Andocides, Isocrates and Lysias. speeches

Keywords: political realism; history of political and legal doctrines; ancient Greek rhetorical

From the perspective of the history of political and legal doctrines, a dichotomous way of looking at reality through the prism of the struggle between realism and idealism is one of the classical approaches to social sciences. Obviously, this division does not exhaust all the possibilities, but often it becomes a point of reference for other trends in political and legal thought. Therefore, the discussions on this topic are all the time of universal and timeless character, not losing their importance.

The approach marked with the features of realistic thinking can be found not only in politics, because it also occurs in many other contexts of philosophical, 
artistic or legal nature. Also, within the political realism itself the multiplicity of its variations can be undoubtedly distinguished. Differences in assumptions and diversity of details allow to identify, i.a., realism relating to internal policy and that associated with international relations. Similarly, just a little differently, this issue should be analyzed from the perspective of the classical approach, and differently from the neoclassical approach.

The basic source of knowledge for the political realism idea in the classical sense is the achievements of politicians, historians and philosophers, who, after all, are often at the same time creators of political and legal thought. Indeed, Book I of Plato's State brings us a statement of a sophist Thrasymachus, which is significant, also from the viewpoint of political realism, and for whom justice means nothing else but what is in the interest of the stronger ${ }^{1}$. Justice, in his opinion, should therefore be associated with the rules imposed by the stronger, the decisions of those in power, whose volition is thus equal to law ${ }^{2}$. It seems, however, that in the research on political realism, one should, based on subsidiarity, also use the message found in rhetorical speeches, recorded and preserved until now. Taking these reservations into account, the author's intention is to analyze, in a rhetorical perspective, the classical European political realism, while narrowing the research field, outlined in this way, to international relations. The subject of the analysis are, therefore, ancient Greek rhetorical speeches, because, according to the hypothesis, they may prove to be a valuable source of understanding for the development of the political realism idea. This assumption, which requires an appropriate confirmation, also prompts to specify further the research fields. Thus, ancient Greek rhetorical speeches, generally delivered in connection with ongoing or intended armed conflicts, were analyzed as the subject of the analysis. Since war is, apart from many military, economic and social consequences, also a catalyst for the development of political and legal thought, especially of the political realism idea. It should be emphasized that a manifestation of this doctrine may also be those of the rhetorical speeches which in their content encourage people to make peace.

In the reference literature, the issues discussed in this article are relatively rarely presented. After all, it has become an inspiration to take up the subject matter of this work. The hitherto achievements of the science representatives have focused primarily on a description and analysis of the development of the political realism idea and identification of its characteristic features (E. Carr, H. Morgenthau, R. Niebuhr, K. Waltz, R. Aron, J.H. Herz). Moreover, some researchers in the field of political and legal thought have made reconstructions and analyses of normative

Platon, Państwo, Prawa, Kęty 1999, p. 28.

2 B. Szlachta, Realizm w polskiej myśli politycznej XVI wieku (wprowadzenie do badań), [in:] Patriotyzm i zdrada. Granice realizmu i idealizmu w polityce i myśli polskiej, eds. J. Kloczkowski, M. Szułdrzyński, Kraków 2008, p. 13. 
forms of the doctrines whose content is political realism (J. Malarczyk, P. Kimla, A. Rzegocki, B. Szlachta). On the other hand, the rhetorical aspect of the speeches mentioned in the text can be found in the works of such authors as J. Czerwińska, I. Ptaszek or R. Turasiewicz. Taking the above into account, one of the author's intentions, which may be a kind of novelty, is to present, with a certain brevity of the text, the concept of political realism both in theoretical, doctrinal and rhetorical perspective.

The leading research methods used in creating this text include the doxographic method (to describe the basic assumptions of political realism), the historical method (to show the genesis and context of the speeches), the inductive method (by referring to source texts), the content analysis, and the comparative method (to search for some elements of political realism in various rhetorical speeches).

The choice of speeches to be analyzed, due to the size of this text, had to be subjective, although it has been made with an assumption of maintaining a balance between referring to texts appearing in the reference literature, with regard to political realism, relatively often (e.g. the Melian dialogue), and those less commonly known (e.g. the duet of Cleon and Diodotus, Pericles' speech at the Ecclesia [the Popular Assembly] delivered after the second Peloponnesian invasion, speeches by Demosthenes, Isocrates, and Lysias). At the same time, a relevant reservation should be made as to the historical credibility of the quoted speeches. While in case of classical orators (Demosthenes, Isocrates), as a rule, the authenticity of their speeches is not questioned, in relation to the speeches contained in the narrations of historians (Thucydides, Xenophon, Livy) it is more reasonable to assume that they reflect relatively effectively the ideas that are the content of the quoted speeches rather than they constitute their historical record. A reservation of this type is also given by Thucydides himself in Book I of the Peloponnesian War ${ }^{3}$. It is possible, however, to find a standing expressed, i.a. by W. Jaeger, according to which many of the speeches cited by Thucydides (and there are 41 of them) were not delivered at all or had a totally different content ${ }^{4}$. However, it is difficult to share such far-reaching pessimism on this issue. R. Turasiewicz rightly points out that, according to Thucydides' spontaneous statement, the degree of subjectivism and objectivism, and therefore the level of historical authenticity of the speeches that he quotes, is different. The essence, however, is the historian's care for the ideological and content sense, the general tendency (ksympasa gnome, $\xi 0 \mu \pi \alpha \sigma \alpha$

\footnotetext{
3 As we read: "It was difficult to reproduce the speeches made by individual speakers, either before or during the war, both for me, who listened to them myself, and for those who conveyed them to me; so I arranged them as - in my opinion - a given speaker could speak the most appropriately to the circumstances, but I kept as close as possible to the main thought of the speeches actually spoken" (Tukidydes, Wojna peloponeska, vol. 1, Wrocław 2004, pp. 21-22).
}

4 W.W. Jaeger, Paideia, vol. 1, Warszawa 1962, p. 403. 
$\gamma v \omega \mu \eta)$, which allowed him to convey the leading ideas underlying those speeches. Therefore, establishing the historical credibility of specific orations quoted by Thucydides would require answering the question whether he composed a given speech himself, taking into account his own assessment of the situation, or whether he heard it personally, or whether he knew its content from other people's narrations ${ }^{5}$. Considerations of this type, however, are of secondary importance from the viewpoint of history of political and legal doctrines or rhetoric. Assuming the essentially unquestionable value of the historical narration made by Thucydides, it can be assumed that he managed to reflect not as much the content of the speeches as the ideas that determined the meaning of their message. Moreover, considering the historical impact of Thucydides' output, it can be argued that even those speeches that can be called fictitious have become an element of building the European political and legal culture, if only because reading and analyzing these texts has been, after all, a component of classical education for many generations.

Realism has been present for a long time in the study of international relations, so it does not constitute a new perspective in politics ${ }^{6}$. Although, as a type of political culture and historical tradition, political realism was separated in the $19^{\text {th }}$ century, its sources can probably be sought in parallel with the emergence of politics as such. The foundation of this approach is the postulate of a pragmatic perception of reality. This concerns such a perception, which is not disturbed by emotions, such as fear, enthusiasm, panic, aversion, love or hate ${ }^{7}$. Realism, therefore, rejects the need, or even the necessity to adjust the political reality to norms and values defined $a$ priori $i^{8}$. Although they appear in the statements of politicians-realists, they are of secondary importance, and are often used in a utilitarian way to justify rhetorically the political decisions that they have made ${ }^{9}$. Idealism, in turn, assumes the existence of a harmony between the interests, rights and duties of people and social groups, and the consensus between the common good and the good of the individual, or also that such a state can be achieved ${ }^{10}$. It should be remembered at the same time that in international relations, the semantic connotations of the terms "realism" and "idealism" are recognized slightly differently than in the

5 R. Turasiewicz, Wstęp, [in:] Tukidydes, Wojna peloponeska, vol. 1, pp. LIX-LXI.

6 M. Philp, Realism without Illusions, "Political Theory" 2012, vol. 40(5), DOI: https://doi. org/10.1177/0090591712451723, p. 630.

7 P. Kimla, Realizm polityczny, [in:] Stownik historii doktryn politycznych, eds. K. Chojnicka, M. Jaskólski, vol. 5, Warszawa 2012, p. 56. The beginnings of realism in the contemporary form date back to the 1940s and 1950s.

8 A. Orzełek, Poszukiwanie modelu realizmu politycznego. Myśl i publicystyka Aleksandra Bocheńskiego, Lublin 2019, p. 21.

9 T. Raburski, Niccolò Machiavelli: klasyczny realizm i republikanizm, „Filozofia Publiczna i Edukacja Demokratyczna” 2012, vol. 1(1), DOI: https://doi.org/10.14746/fped.2012.1.1.9, p. 115.

10 J.H. Herz, Political Ideas and Political Reality, "The Western Political Quarterly" 1950, vol. 3(2), DOI: https://doi.org/10.2307/443481, p. 162. 
field of philosophy, assuming that they concern the perception of mechanisms and principles governing these relations ${ }^{11}$. Regardless of the above, such considerations are inherently related to a wide range of polemological research ${ }^{12}$. They are also in a close correlation with elitist and conservative concepts ${ }^{13}$.

The variety of classifications of the theories of international relations undoubtedly deserves a separate study, therefore, for the purposes of this text, it should only be noted that the most common model is based on a threefold division, distinguishing the realist, liberalist and globalist trends. In turn, it is quite commonly assumed that realism is the dominant theoretical orientation in the study of international relations ${ }^{14}$. The central categories of this direction are: national interest, sovereignty, military strength and power of the state, and the anarchic nature of the international system, meaning that there is no single centre for decision-making that would act as a regulator and coordinator of interstate relations. This anarchy, in consequence, leads to conflicting relations and a mutual competition, which ultimately forces individual states to care for their own security. It also means that all international agreements are temporary, and their fulfilment depends on the will of the entities concluding them. This volition, in turn, is determined by the constantly changing political situation. An element of this strategy is to build a balance of power system that prevents one country from gaining a dominant position at the expense of others. For these reasons, states must constantly increase their strength potential, which then allows them to achieve their goals and becomes a reference point for taken actions and decisions ${ }^{15}$.

In international relations the basic ideas and assumptions of realism thus include: 1) a pessimistic view of human nature; 2) a conflicting nature of interpersonal relations; 3 ) treating war as a (last) resort in resolving conflicts; 4) the priority nature of the idea of national security and survival of the state; 5) scepticism about the chances of progress in international politics comparable to domestic relations ${ }^{16}$. The fundamental framework of political realism, defined in this way, finds its manifestation in specific actions, which, according to the words of Pericles, should be

11 J. Czaputowicz, Teorie stosunków międzynarodowych: krytyka i systematyzacja, Warszawa 2008, pp. 50-58.

${ }_{12}$ M. Huzarski, Wiedza o polemologii, [in:] Metodologiczna tożsamość polemologii, eds. M. Huzarski, B.M. Szulc, Warszawa 2010, pp. 16-17.

13 P. Ish-Shalom, The Triptych of Realism, Elitism, and Conservatism, "International Studies Review” 2006, vol. 8(3), DOI: https://doi.org/10.1111/j.1468-2486.2006.00602.x, pp. 441-468.

${ }_{14}$ S. Forde, International Realism and the Science of Politics: Thucydides, Machiavelli, and Neorealism, "International Studies Quarterly" 1995, vol. 39(2), DOI: https://doi.org/10.2307/2600844, p. 141.

15 J. Czaputowicz, op. cit., pp. 58-59.

${ }^{16}$ R.H. Jackson, G. Sørensen, Wprowadzenie do stosunków międzynarodowych. Teorie i kierunki badawcze, Kraków 2006, p. 70. 
preceded by instruction in words ${ }^{17}$. This is also the reason why the subject of this text is rhetorical speeches treated as the source of the realism idea.

According to all leading representatives of classical realism, such as Thucydides, Machiavelli or Hobbes, one of the paradigms of human behaviour is the lust for power. On the other hand, realists consider sovereignty to be the most important feature of the state, from which it can be concluded that the goal of each state is to implement such a policy and take such actions that will consolidate the strength of the state ${ }^{18}$. Consequently, international politics appears in this context as a stage where rivalries and conflicts arise constantly in order to defend national interests and ensure the continuity of the state. The only determinant of this policy effectiveness is the level of implementation and protection of the national interest. The assumption about the invariability of human nature and the international relations resulting from it prompts representatives of this trend to take the position according to which the realistic theory of international relations is adequate not only at strictly defined historical stages, but has the value of timelessness ${ }^{19}$. This does not mean, of course, that the concept does not undergo a doctrinal evolution. There are differences between the positions of individual representatives of realistic concepts, which is, moreover, reflected in the reference literature due to different varieties of this direction. And so, within the intellectual traditions of this doctrine one distinguishes complex realism (Thucydides), fundamentalism (N. Machiavelli), structural realism (T. Hobbes) and constitutionalism (J.-J. Rousseau ${ }^{20}$. J. Czaputowicz, in turn, proposes to distinguish three currents of realism: practical realism (M. Weber, E. Carr), classical realism (R. Niebuhr, H. Morgenthau) and structural realism (K. Waltz) ${ }^{21}$.

While looking for sources of the idea of European political realism, one cannot miss, even in a concise way, Homeric poems. They were like holy books from which history, religion, ethics and poetry were learned. Homeric images of gods became an indispensable element of the Greek culture, which then, taken over by the Romans, permanently shaped the foundations of the European identity ${ }^{22}$. After all, from the very beginning of its existence, the Iliad was treated as a script, i.e.

17 Tukidydes, Wojna peloponeska, vol. 1, p. 151.

18 A. Rzegocki, Racja stanu a polska tradycja myślenia o polityce, Kraków 2008, p. 68.

19 As Pericles was to say in the epitaph in honour of the soldiers killed in the Peloponnesian War: "We always judge the events ourselves and try to form an accurate judgement for ourselves; we do not take the position that words are harmful for acts, but that first one must be instructed by words before they proceed to deeds" (R.H. Jackson, G. Sørensen, op. cit., pp. 70-72).

20 A. Urbanek, Realistyczna wizja bezpieczeństwa - próba systematyzacji koncepcji, „Security, Economy \& Law" 2017, no. 4, p. 243.

${ }^{21}$ J. Czaputowicz, op. cit., pp. 58-73.

${ }^{22}$ T. Sinko, Wstęp, [in:] Homer, Iliada, Wrocław 2004, p. LXXXVII. 
a text that was learned by heart, even if it was not recreated literally afterwards ${ }^{23}$. If so, then the behaviour of the immortals depicted by Homer both reflected and shaped in the future human attitudes and ideas. Disputes, which are one of the key elements of the Iliad, take place both in the space ruled by gods and people. But the gods often become active participants in the lives of mortals, interfering with the course of battles and influencing directly the behaviour of the heroes, and are often guided by feelings, which gives them typically human qualities. Here, then, one can also search for the idea of realism, for example, by referring to the dialogue of Zeus and Hera from Book IV of the Iliad. Zeus, saying that Troy is the nicest city of his heart, at the same time is able to sacrifice it as far as Hera will not intercede for other cities, which he will want to demolish. And Hera replies like that:

I love three cities, as I have chosen them over others:

In Argos, in Sparta, and in Mycenae I have the only delight,

But when they are hateful to you, let them perish. [...]

From now on let us want to succumb to each other:

You will be helpful to me, and I will be helpful to you,

And so, nothing can resist our will in heaven $[\ldots]^{24}$.

In this dialogue we can see, already emerging, the idea of the primacy of the decision-makers' interests (Zeus, Hera) over the individual interests of the weaker or dependent entities (Troy, Argos, Sparta, Mycenae). Similarly, one can also look here for other rules of political realism, such as the lack of equality of the parties, the balance of powers or treating contracts as acts of a temporary nature whose observance is always dependent on the current political needs or the political situation.

However, moving from the important, albeit literary, sources of political realism to strictly historical events and the related rhetorical speeches, one should, first of all, refer to Thucydides, whose study of the Peloponnesian War deserves a privileged place ${ }^{25}$. After all, this historian is considered quite commonly in the reference literature as the father of political realism ${ }^{26}$. Although it should be emphasized that there are also authors who consider him not so much a founder but a critic of realism ${ }^{27}$.

${ }^{23}$ W. Grzybowski, Metafora i piękno w Iliadzie Homera, „Nurt SVD” 2017, no. 1, p. 318.

${ }^{24}$ Homer, op. cit., pp. 68-69.

25 M.T. Clark, Realism Ancient and Modern: Thucydides and International Relations, "Political Science and Politics" 1993, vol. 26(3), DOI: https://doi.org/10.2307/419989, p. 391.

26 As D. Polansky (Nietzsche on Thucydidean Realism, "The Review of Politics" 2015, vol. 77(3), DOI: https://doi.org/10.1017/S0034670515000352, pp. 427-428) writes, the first significant philosopher and writer to describe Thucydides as a realist was F. Nietzsche.

27 P.J. Ahrensdorf, Thucydides' Realistic Critique of Realism, "Polity" 1997, vol. 30(2), DOI: https://doi.org/10.2307/3235218, pp. 232-233. See J. Monten, Thucydides and Modern Realism, "International Studies Quarterly" 2006, vol. 50(1), DOI: https://doi.org/10.1111/j.1468-2478.2006.00390.x. 
Regardless of the above dispute, it should be stated that while the work of another historian of that time, Herodotus, is characterized by the tone of a talk and a kind of benevolent naivety, the fundamental assumption and goal of Thucydides' work became values essential from the viewpoint of realism, i.e. rationalism devoid of an emotional touch and cold criticism ${ }^{28}$. Anyway, already in the first book of his work, Thucydides wrote that his account, devoid of fairy tales, might seem less interesting, but due to its meticulousness it would have all the qualities that would give it an imperishable value ${ }^{29}$. Subject to the remarks made at the outset, concerning historicity of the rhetorical speeches cited by the author of Peloponnesian War, in searching for sources of political realism they seem to be a relatively precious material. These orations play a significant role in this work because they present both the motives of action, directions of thinking and plans of both individuals, political parties and entire states ${ }^{30}$. In the reference literature, in this context, the so-called Melian Dialogue (416 B.C.) is mentioned the most commonly. And although it is a largely correct approach, undoubtedly the same ideas that are expressed in this dialogue can be found earlier in the discourse between Cleon and Diodotus in the course of the Ecclesia in Athens in 427 B.C. The background of the speakers' clash was a resolution taken by the Athenians to murder all adult Mytileneans (men) and, at the same time, to sell women and children into slavery. This was to be not only a punishment for the rebellion and an attempt to sever ties with the Delian League (Confederacy of Delos, Athenian League), but also a warning to other allies wishing to break with the Athenian hegemony. When after the siege Mytilene fell, retaliatory tendencies were felt at the Ecclesia. Therefore, the above-mentioned decision was made, but as reported by Thucydides the next day, the Athenians, overwhelmed with grief, found the decision to exterminate the entire city to be too cruel. It was opted therefore that sanctions against the residents of the city should be made once again a part of the agenda. Then two views clashed, represented on one side by Cleon, and on the other by Diodotus. Cleon was a supporter of keeping the decision once made. When describing the essence of the treason of Mytilene's inhabitants, he argued that a treatment of the rebels that would be too lenient could be a bad example for others. He seemed to speak in a language that a Roman poet and playwright, Lucius Accius, would put later into the sentence oderint dum metuant ("Let them hate, as long as they are afraid") $)^{31}$. In Cleon's statements, one can find a direct reference to the principles of political realism, for example, when he said, "They obey you, not because you treat them kindly to your detriment, but because

${ }^{28}$ R. Turasiewicz, Tukidydes, Wrocław 1987, p. 14.

29 Tukidydes, Wojna peloponeska, vol. 1, p. 22.

${ }_{30}$ J. Czerwińska, Retoryczny aspekt prozy historycznej Tukidydesa, „Collectanea Philologica” 2002, no. 4, p. 77.

${ }^{31}$ R. Kulesza, Wojna peloponeska, Warszawa 2006, p. 112. 
you are their masters, and you are masters thanks to your strength, and not thanks to their kindness to you"32. He also warned, in a spirit of realism as well, against succumbing to feelings when making political decisions. He even stated that there are three things that are the most dangerous to the state: pity, a charm of words, and indulgence. He ended his tirade with a call to punish the inhabitants of Mytilene in a manner appropriate to their deed, which would become a warning to the rest of the allies, and the Athenians would not be forced to "wage wars with their own allies neglecting fighting with their enemies" ${ }^{\prime 3}$.

Diodotus was a supporter of mitigating the sanctions, although he argued with Cleon primarily not in the context of the goals of Athens' imperial policy, but rather of the methods used to achieve them. In his opinion, a punishment that is too severe will not only be unfair, but, above all, it will strengthen the determination and resistance of the rebels, which in turn will make obtaining income from them impossible, which is, after all, a significant aspect during the ongoing $\operatorname{war}^{34}$. Moreover, according to the Athenian orator, punishing all the inhabitants could result in a loss of favour on the part of other cities' residents, since that penalty would affect both the guilty and the innocent. Despite his emotional speech, Diodotus also refers to the pragmatism of the audience saying at the end of his speech:

Do not follow either pity or indulgence - these are the reasons that I reject as well - but heed only the arguments included in my speech: judge with caution the Mytileneans, sent by Paches as guilty ones, and leave the others alone. [...] because whoever makes a good decision in relation to opponents is stronger than that who uses blind and mindless violence against them ${ }^{35}$.

The inequality in international relations and naturalism, typical of political realism, are also reflected in the famous Melian dialogue, the content or at least the essence of which is known from Thucydides' narration. Despite their ties with Sparta, the people of Melos wanted to remain neutral during the Peloponnesian War. The Athenians demanded, however, under a threat of total annihilation, that the inhabitants of Melos should join the Delian League. When the Melians finally refused, the Athenian army under Philocrates captured the city, and a cruel fate befell the survivors. The men were murdered, whereas the women and children were sold into slavery. What is important from the viewpoint of the title of this article is the fact that in the course of the negotiations the Athenian envoys rejected the moral aspect of relations between the countries preaching at the same time a view

32 Tukidydes, Wojna peloponeska, vol. 1, p. 232.

33 Ibidem, p. 237.

${ }^{34}$ E. Karolczuk, Sprzeczności w funkcjonowaniu demokracji ateńskiej, „Sztuka i Dokumentacja” 2017, no. 16, pp. 38-39.

35 Tukidydes, Wojna peloponeska, vol 1, pp. 242-243. 
that violence is just, and law of the stronger stems from the law of nature ${ }^{36}$. The Athenians talked like that:

After all, just like you, we know perfectly well that justice in human relations is the decisive moment only then, when on both sides equal forces can secure it; as for the range of possibilities, the stronger achieve their goals, and the weaker give way. [...] We believe that both the gods, as we imagine them, and the people themselves, because of their inherent qualities, quite openly, everywhere and always rule over those who are not as strong as they are. We did not invent this law either and we did not apply it first, but we use it, taking it from our ancestors and passing it on to posterity as the immutable law. We also know that you and everyone else, having power equal to ours, would do the same ${ }^{37}$.

The Athenian envoys repudiate openly the moral context of their demands and say directly that they do not want to rely on the fact that they deserve such domination because of the victory over the Persians or because the Melians have hurt them. Instead, they invoke the logic of force and expect the resignation of the weaker in accordance with the law of nature understood in this way ${ }^{38}$. The realism of the Athenian speakers is also manifested in their belief that there is no place for neutrality in the ongoing conflict, and the acceptance of friendship declared by the Melians, in the eyes of other subjugated cities, may be interpreted as a sign of weakness, which the Athenians cannot afford. Thus, there is a lack of belief in the lasting friendship, as in another part of this dialogue, when the Athenians prove the lack of hope for the inhabitants of Melos to get help from Sparta because of their kinship with them. They argue that the Lacedaemonians will not help them, because it will not be beneficial for them, and that providing help depends not on sympathy or kinship, but on the calculation of strength. The Athenian envoys also warn of being guided by emotions while taking political decisions, i.e. appealing to their own honour and to a threat of falling into disgrace. Instead, they say that this conduct is a sign of rashness, and it is no disgrace to give way to a more powerful state, in particular if it puts moderate conditions ${ }^{39}$. Thus, like in a lens, the principles of political realism concentrate in this dialogue: justice based on the logic of force, rejection of wishful thinking and resorting to providence, negation of permanence of political alliances and basing them on common descent instead of the calculation of benefits, and finally the belief that there is no possibility to maintain neutrality effectively in the event of a hegemonic war.

${ }^{36}$ R. Turasiewicz, Tukidydes..., p. 44.

37 Tukidydes, Wojna peloponeska, vol. 2, Wrocław 2004, pp. 465-471.

38 Demosthenes also spoke about the imposition of their will by the stronger in 351 B.C., defending the Rhodian democratic party. He claimed that the essence of law in democratic countries is equality of both the weak and the strong, while in international relations "the stronger dictate laws to the weaker". See Demostenes, Wybór mów, Wrocław 2005, p. 55.

39 Tukidydes, Wojna peloponeska, vol. 2, pp. 466-473. 
Undoubtedly, one of the determinants of political realism in international relations is the concept of maintaining the balance of power. Its reflection can already be found in Thucydides' beliefs, who perceived the main cause of the outbreak of the Peloponnesian War in the feeling of imbalance that had been generated ${ }^{40}$. The idea of maintaining the balance of power also appears in the works of other classical authors: N. Machiavelli (The Prince), T. Hobbes (Leviathan) and C. von Clausewitz (On War). But the achievements of ancient orators also prove the practical knowledge of this concept already in antiquity. As an example, one may use Demosthenes' speech delivered in defence of the inhabitants of Megalopolis, who turned to the Athenians for help, because they were threatened by the Lacedaemonians. Providing this help was not an obvious matter, because at that time, Athens, for fear of the growing power of Thebes, remained in an alliance with Sparta. Therefore, supporters of maintaining that alliance were opposed to helping the inhabitants of Megalopolis. Demosthenes, however, guided by the balance of power principle, had a different opinion. He believed that the interest of the Athenian state lay in the situation that neither Thebes, nor Sparta, should not grow in such strength, which could ultimately threaten Athens ${ }^{41}$. Demosthenes admonished the assembled:

Perhaps, nobody will deny that it is in our country's interest to weaken both the Lacedaemonians and the Thebans. [...] It is our duty not to let the rise of one of these states precede the collapse of the other, and therefore that the rise of Lacedaemonian power without our knowledge is accompanied by such a loss of power by Thebes that would threaten our political interests. [...] our desire is to deprive them both of the possibility to cause harm to $\mathrm{us}^{42}$.

After this speech, Demosthenes, also in the spirit of realism, stated that he had delivered it without succumbing to feelings, i.e. sympathy or hatred towards one or the other side, and the only thing that he was guided by was the interest of his state ${ }^{43}$.

The thought of the primary character of the state interest, in the collision with the interests of individuals, was highlighted in turn in the speech of Pericles, delivered after the second Peloponnesian invasion. It was then that Attica was destroyed again, and pestilence was spreading all over the city at the same time. The people of Athens blamed "the first citizen" for the calamities caused by the war with all its consequences. That is why, being also a strategist, Pericles convened the Ecclesia in order to lift the spirit of the Athenians and soften their anger. He said that a citizen obtains more benefits if the country as a whole is doing well than if he is doing

${ }^{40}$ S. Maciejewski, Filozoficzne korzenie realizmu politycznego, [in:] Teoria realizmu w nauce o stosunkach międzynarodowych. Założenia i zastosowania badawcze, eds. J. Czaputowicz, E. Haliżak, Warszawa 2014, pp. 58-59.

${ }^{41}$ R. Turasiewicz, Wstęp do mowy w obronie mieszkańców Megalopolis, [in:] Demostenes, op. cit., pp. 30-31.

${ }^{42}$ Demostenes, op. cit., pp. 32-33.

${ }^{43}$ Ibidem, p. 42. 
well, but the state collapses. He put it metaphorically in the words: "If the state is able to withstand some storms in the lives of individuals, and the individual is not able to withstand the storms threatening the state, then is it not necessary to defend this state together with all our strength, and not to act as you are doing now?"44.

Settlement of the above dilemma between the individual and collective interest is reflected in particular in emergency situations caused by an armed conflict. What is interesting and worth emphasizing, the political realism present in ancient rhetorical speeches was manifested both during orations, the purpose of which was to preserve peace, but also when they were to create justification for the outbreak of war. Admittedly, in the speech quoted above Pericles said that if one has a choice, and the country is doing well, "a war is the highest madness". However, in his opinion, the Athenians, faced with a conflict with Sparta, had no choice and either they would have had to yield and submit to orders of the Lacedaemonians or, by exposing themselves to the danger, they could have won. Therefore, defending his current attitude, he stated that one should rebuke the one who avoids the danger, and not the other who decides to take it in such a situation ${ }^{45}$. Realism, therefore, in his opinion, spoke in that case for the continuation of the war.

It should be emphasized that also speeches for peace can be a good example to illustrate the complexity of the political realism concept. Giving the voice to Demosthenes once again, it is worth recalling in this context his speech on peace, given in the autumn of 346 B.C., in which he defended the idea of the concluded treaty (called the Peace of Philocrates) with Philip II of Macedon. Under this agreement, i.a., the Athenians had to agree to a concession on their allies (the Phocaeans), against whom Philip waged the war. So, when Philip's envoys arrived in Athens, with an accusation of sheltering fugitives from Phocidae, the political situation became extremely tense. And here, in the name of political realism, Demosthenes, after all an intransigent opponent of Philip, calmed the people at the Ecclesia, arguing that in the current political situation of Athens, a peace with Philip was already an accomplished fact, and breaking it at that moment would be a suicide $\mathrm{act}^{46}$. Therefore, he argued that gaining new allies, increasing the state's income or giving the state another favour cannot take place at the expense of the peace agreement concluded with Philip. However, he did not hide from the audience his doubts whether that peace was worthy of Athens or especially beneficial to it. Speaking to the assembled Athenians, he argued:

[...] whatever there may be [peace - M.N.], it would be more appropriate for your current state interests not to make it at all than to break it now, because the numerous losses that we have suffered

${ }^{44}$ Tukidydes, Wojna peloponeska, vol. 1, pp. 164-165.

${ }^{45}$ Ibidem, p. 165.

${ }^{46}$ R. Turasiewicz, Wstęp do mowy o pokoju, [in:] Demostenes, op. cit., pp. 118-119. 
mean that today we would be waging war with a greater risk and in much more difficult conditions than then ${ }^{47}$.

He ended his speech with a conviction that peace offered more benefits than war, and therefore it would be "an act of great political naivety and blindness" to provoke the outbreak of a conflict ${ }^{48}$.

Another speaker, Andocides, who was a member of the Athenian delegation at a conference convened by Sparta in 392/391 B.C., spoke similarly for peace. Upon his return to Athens, it was Andocides who reported to the Popular Assembly the negotiated terms of peace. As it turned out, however, the delegation had exceeded its ambassadorial powers, and the Ecclesia found the presented conditions unacceptable. The envoys were accused of acting contrary to the given instructions, of misleading the Council and accepting material benefits. As a result of these accusations, the envoys were sentenced to exile or death ${ }^{49}$. Before that happened, however, Andocides had said:

[...] so why should we continue to fight? For our city to be free? Well, it is free! Maybe, so that we could build walls? But based on the peace treaty, we are allowed this too! Maybe, so that we could build new ships, and renovate and keep the old ones for ourselves? But we are allowed to do so as well [...]. So, if we do not have the reason, with whom and for what to fight, are there any reasons why we should not strive for peace by all possible means? $?^{50}$

It also happened among ancient orators that their task was both to incite waging war and to encourage maintaining peace in the name of the Panhellenic unity ${ }^{51}$. It was like that, for example, in the case of Lysias' Olympic Oration or Isocrates' Panegyricus. The former, a logographer and consultant for trial parties, well known in Athens, was also to be the author of a political speech, the content of which was to urge removal of Dionysius I from power in Syracuse and to liberate Sicily from the influence of the Syracusan state. It is uncertain whether that oration was delivered by Lysias himself or whether it was written for someone else. Similarly, however, as in the case of speeches known from the report of Thucydides its ideological message is more important, in the context of this article, than establishment of its authorship or actual delivery. The speaker urged, in the face of the ongoing Corinthian war (395-387 B.C.), for general consensus due to the danger that threatened the Greek world from two sides: the tyrant of Syracuse, Dionysius I and the

${ }^{47}$ Demostenes, op. cit., pp. 123-124.

48 Ibidem, p. 129.

49 I. Ptaszek, Wstęp, [in:] Andokides, Mowy, Kraków 2002, pp. XIII-XIV.

${ }^{50}$ Andokides, op. cit., p. 61.

${ }^{51}$ Panhellenic ideas, as a peculiar manifestation of political realism, can also be found in the speeches of Gorgias of Leontinoi (Olympic Speech) and Isocrates (On the Peace, Panathenaicus). 
Persian state ${ }^{52}$. The Greeks were very seriously afraid of the alliance of these two powers, which, after their victory over the Hellenes, could divide their territory between themselves ${ }^{53}$. Hence, Lysias exhorted:

[...] we must abandon the war that we are waging against each other and pursue our common salvation, be ashamed of our past deeds and fear the future, compete with our ancestors who, having driven out tyrants, established freedom common to all and caused that barbarians who had coveted someone else's land were deprived of their own. [...] So let us not wait for the mighty forces of both our enemies to fall on us, but while it is still possible, let us stop their armed pride ${ }^{54}$.

Another great orator of Athens, Isocrates, took the same Panhellenic topic in his speech Panegyricus, making a review of Greek history (in the perspective of Athens and Sparta), with particular emphasis on the period between the invasion of Xerxes, and the times of Isocrates ${ }^{55}$. As we read in this oration:

The speech on this matter is simple and easy; for we will not be able to have a sure peace if we together do not organize a war against the barbarians, nor we will achieve an internal agreement among the Greeks, unless we have the benefit from a common source and put ourselves in danger together ${ }^{56}$.

Politics is the art of the possible. Politicians-realists, therefore, pursue only those goals that are within their reach, and they do so with full awareness of the limitations and obstacles that they face ${ }^{57}$. The above-mentioned examples of the rhetorical speeches confirm the hypothesis put forward at the beginning that they can be a subsidiary source of learning about the idea of political realism. Due to the fact that they were spoken or written in specific political and legal contexts, those speeches are also an interesting source material for an analysis of realism from the perspective of political life practice. This applies in particular to the so-called two-reason speeches ( $\left.\delta l \sigma \sigma o i{ }^{\prime} o^{\prime} \gamma o l\right)$, a large number of which can be found in the unforgettable work of Thucydides. In addition, his decision to show the political affairs presenting the arguments of both parties to the dispute, increases greatly a chance of objectivity of such analyses.

The value of the ancient Greek rhetorical speeches is also due to the fact that the Greek culture was the culture of the spoken word, and the orators often influenced the course of public affairs thanks to their oratory art. The examples of speeches cited in this text allow the conclusion that all the basic categories of

52 R. Turasiewicz, Wprowadzenie do mowy olimpijskiej, [in:] Lizjasz, Mowy, Kraków 1998, p. 254.

${ }^{53}$ Idem, Życie i twórczość Lizjasza. Początki praktyki i teorii retorycznej, Kraków 1999, p. 285.

${ }^{54}$ Lizjasz, op. cit., pp. 255-256.

55 W.E. Thompson, Isocrates on the Peace Treaties, “The Classical Quarterly" 1983, vol. 33(1), DOI: https://doi.org/10.1017/S0009838800034303, p. 78.

56 Izokrates, Panegiryk, „Filomata” 1996, no. 439-440, p. 406.

57 R. Goodin, Political Ideals and Political Practice, "British Journal of Political Science" 1995, vol. 25(1), DOI: https://doi.org/10.1017/S0007123400007055, p. 37. 
political realism are reflected in them, and thus they can be a source of learning about the development of this concept. And so, the dialogue of Zeus with Hera from Book IV of the Iliad illustrates the ideas of the primacy of the stronger over the weaker, the balance of power and the temporary nature of the concluded contracts. The dispute between Cleon and Diodotus reveals the principle of the domination of power and not yielding to feelings when making political decisions. In turn, the discourse between the Athenian envoys and the Melians brings the concept of rejecting moral contexts in international relations and the principle of yielding to the stronger, of justice based on the logic of force, of no room for neutrality, of the impermanence of relationships built on bonds of friendship and kinship, of negation of the permanence of political alliances and the dominance of the account of benefits in relation to contacts between countries. On the other hand, Demosthenes, defending the inhabitants of Megalopolis, explained the understanding of the idea of the state's interest in the context of the balance of power concept and emphasized the priority nature of the issue of national security and the state's survival. The thought about the dominance of the state interest which is the fundamental concept for political realism was reflected, in turn, in the speech of Pericles and the speeches of Demosthenes, Andocides, Lysias and Isocrates, which, depicting the principle of anarchy of the international system, had as their subject the issues related to the conclusion of peace or waging of war.

The above principles, ideas or concepts resulted from the logic of the course of political affairs, but what should be emphasized, they also spontaneously built the ideological identity of the supporters of political realism. Even if the creation of these principles was less or more conscious for the speakers, no doubt the orations have become the constituent elements allowing for the development and consolidation of political realism, which today is still the dominant theoretical concept in the study of international relations.

\section{REFERENCES}

Ahrensdorf P.J., Thucydides' Realistic Critique of Realism, "Polity" 1997, vol. 30(2),

DOI: https://doi.org/10.2307/3235218.

Andokides, Mowy, Kraków 2002.

Clark M.T., Realism Ancient and Modern: Thucydides and International Relations, "Political Science and Politics" 1993, vol. 26(3), DOI: https://doi.org/10.2307/419989.

Czaputowicz J., Teorie stosunków międzynarodowych: krytyka i systematyzacja, Warszawa 2008.

Czerwińska J., Retoryczny aspekt prozy historycznej Tukidydesa, „Collectanea Philologica” 2002, no. 4.

Demostenes, Wybór mów, Wrocław 2005.

Forde S., International Realism and the Science of Politics: Thucydides, Machiavelli, and Neorealism, "International Studies Quarterly" 1995, vol. 39(2), DOI: https://doi.org/10.2307/2600844. 
Goodin R., Political Ideals and Political Practice, "British Journal of Political Science" 1995, vol. 25(1), DOI: https://doi.org/10.1017/S0007123400007055.

Grzybowski W., Metafora i piękno w Iliadzie Homera, „Nurt SVD” 2017, no. 1.

Herz J.H., Political Ideas and Political Reality, "The Western Political Quarterly" 1950, vol. 3(2), DOI: https://doi.org/10.2307/443481.

Homer, Iliada, Wrocław 2004.

Huzarski M., Wiedza o polemologii, [in:] Metodologiczna tożsamość polemologii, eds. M. Huzarski, B.M. Szulc, Warszawa 2010.

Ish-Shalom P., The Triptych of Realism, Elitism, and Conservatism, "International Studies Review" 2006, vol. 8(3), DOI: https://doi.org/10.1111/j.1468-2486.2006.00602.x.

Izokrates, Panegiryk, „Filomata” 1996, no. 439-440.

Jackson R.H., Sørensen G., Wprowadzenie do stosunków międzynarodowych. Teorie i kierunki badawcze, Kraków 2006.

Jaeger W.W., Paideia, vol. 1, Warszawa 1962.

Karolczuk E., Sprzeczności w funkcjonowaniu demokracji ateńskiej, „Sztuka i Dokumentacja” 2017, no. 16.

Kimla P., Realizm polityczny, [in:] Stownik historii doktryn politycznych, eds. K. Chojnicka, M. Jaskólski, vol. 5, Warszawa 2012.

Kulesza R., Wojna peloponeska, Warszawa 2006.

Lizjasz, Mowy, Kraków 1998.

Maciejewski S., Filozoficzne korzenie realizmu politycznego, [in:] Teoria realizmu w nauce o stosunkach międzynarodowych. Założenia i zastosowania badawcze, eds. J. Czaputowicz, E. Haliżak, Warszawa 2014.

Monten J., Thucydides and Modern Realism, "International Studies Quarterly" 2006, vol. 50(1), DOI: https://doi.org/10.1111/j.1468-2478.2006.00390.x.

Orzełek A., Poszukiwanie modelu realizmu politycznego. Myśl i publicystyka Aleksandra Bocheńskiego, Lublin 2019.

Philp M., Realism without Illusions, "Political Theory" 2012, vol. 40(5),

DOI: https://doi.org/10.1177/0090591712451723.

Platon, Państwo, Prawa, Kęty 1999.

Polansky D., Nietzsche on Thucydidean Realism, "The Review of Politics" 2015, vol. 77(3), DOI: https://doi.org/10.1017/S0034670515000352.

Ptaszek I., Wstęp, [in:] Andokides, Mowy, Kraków 2002.

Raburski T., Niccolò Machiavelli: klasyczny realizm i republikanizm, „Filozofia Publiczna i Edukacja Demokratyczna” 2012, vol. 1(1), DOI: https://doi.org/10.14746/fped.2012.1.1.9.

Rzegocki A., Racja stanu a polska tradycja myślenia o polityce, Kraków 2008.

Sinko T., Wstęp, [in:] Homer, Iliada, Wrocław 2004.

Szlachta B., Realizm w polskiej myśli politycznej XVI wieku (wprowadzenie do badań), [in:] Patriotyzm i zdrada. Granice realizmu i idealizmu w polityce i myśli polskiej, eds. J. Kloczkowski, M. Szułdrzyński, Kraków 2008.

Thompson W.E., Isocrates on the Peace Treaties, “The Classical Quarterly” 1983, vol. 33(1), DOI: https://doi.org/10.1017/S0009838800034303.

Tukidydes, Wojna peloponeska, vol. 1, Wrocław 2004.

Tukidydes, Wojna peloponeska, vol. 2, Wrocław 2004.

Turasiewicz R., Tukidydes, Wrocław 1987.

Turasiewicz R., Wprowadzenie do mowy olimpijskiej, [in:] Lizjasz, Mowy, Kraków 1998.

Turasiewicz R., Wstep, [in:] Tukidydes, Wojna peloponeska, vol. 1, Wrocław 2004.

Turasiewicz R., Wstęp do mowy o pokoju, [in:] Demostenes, Wybór mów, Wrocław 2005. 
Turasiewicz R., Wstęp do mowy w obronie mieszkańców Megalopolis, [in:] Demostenes, Wybór mów, Wrocław 2005.

Turasiewicz R., Życie i twórczość Lizjasza. Początki praktyki i teorii retorycznej, Kraków 1999.

Urbanek A., Realistyczna wizja bezpieczeństwa - próba systematyzacji koncepcji, „Security, Economy \& Law" 2017, no. 4.

\section{STRESZCZENIE}

Z perspektywy historii doktryn polityczno-prawnych dychotomiczny sposób spojrzenia na rzeczywistość przez pryzmat zmagań między realizmem a idealizmem stanowi jedno z klasycznych ujęć nauk społecznych. Podstawowym źródłem poznania idei realizmu politycznego jest dorobek polityków, historyków czy filozofów, którzy często znajdują się jednocześnie w gronie twórców myśli polityczno-prawnej. W badaniach nad realizmem politycznym należy jednak, na zasadzie subsydiarności, korzystać także z przekazu znajdującego się w utrwalonych i zachowanych do dzisiaj mowach retorycznych. Uwzględniając te zastrzeżenia, przedmiotem artykułu jest analiza - w retorycznej optyce - klasycznego realizmu politycznego, z jednoczesnym zawężeniem pola badawczego do stosunków międzynarodowych. Przedmiotem analizy są wybrane starożytne greckie mowy retoryczne takich autorów, jak Kleon, Diodotos, Perykles, Demostenes, Andokides, Izokrates i Lizjasz.

Słowa kluczowe: realizm polityczny; historia doktryn polityczno-prawnych; starożytne greckie mowy retoryczn 